\title{
Welcome to Environmental Microbiome
}

\author{
Joy E. M. Watts
}

I am delighted to serve as Editor-in-Chief for Environmental Microbiome, sister publication to Microbiome and Animal Microbiome. We are kicking off Environmental Microbiome with a research article by Barbara Cania and colleagues: A long-term field experiment demonstrates the influence of tillage on the bacterial potential to produce soil structure-stabilizing agents such as exopolysaccharides and lipopolysaccharides [1]. This article looks at how the common agricultural practice of tilling can disrupt the potential of bacteria to produce the natural compounds that 'glue' soil particles together - this 'gluing' effect helps prevent soil erosion.

Environmental microbiology can be loosely defined as the study of microbes, their functions, and interactions in all habitats on Earth (and beyond). This is a burgeoning research area that covers air, soil and aquatic systems, astrobiology, biogeochemical cycles, plant-soil interactions, extreme environments, and spatial, temporal and perturbation studies. Unfortunately, due to the nonculturability of most environmental species, our understanding of microbial community composition and function is somewhat driven by technological innovation. A proliferation of 16S rRNA gene studies in the 1990s started to reveal the diversity present in environmental systems. The increasing ease and availability of sequencing-based approaches enabled larger fragments of environmental DNA to be cloned [2]. This was followed shortly after by early metagenomics studies such as Rondon et al. 2000 [3], and genome reconstruction from environmental samples [4]. These omics-based tools have enabled new insights into microbial diversity, function, and the complex ecological interactions therein. This is an exciting time and continuing innovations in sequencing technology and downstream analysis have now made assessments of complex environmental microbiomes commonplace and also revealed how much diversity is left to discover!

This journal will provide a forum to publish hypothesisdriven environmental microbiome studies such as marker gene surveys, metagenomes, metatranscriptomes, metaproteomes, metabolomes, microbial genome reconstruction, and single-cell analysis from environmental habitats. Previously, many studies have focused on bacterial and archaeal microbiome analysis, but to obtain a more holistic view of ecological interactions we should aim to include the environmental mycobiome and virome to better understand different systems. Understanding the function and activities of microbial dark matter and the rare biosphere will be a major focus for the journal, and utilising improved technologies such as single-cell sequencing analysis will also provide valuable insights. New methodologies, theoretical community analysis, and development of bioinformatics tools are also welcome due to their importance in moving our understanding forward.

The journal is transitioning from Standards in Genomic Sciences and, as such, we are in the fortunate position of already having an Impact Factor that we can build upon. The Editorial team for this journal is diverse and reflects the broad research areas that will be reflected in this publication. As a sister journal to Microbiome and Animal Microbiome the same high standards of openness and transparency will be employed. To promote open access science, which is crucial for ensuring the most impact from published research, all articles published in Environmental Microbiome will be freely available through the journal web portal and within major research publication databases such as PubMed Central. Also, because authors, not the publisher will hold the copyright to their work, they will be free to distribute published articles.

The editorial team at Environmental Microbiome hope that you will support this endeavour by submitting your research studies and furthering our understanding of environmental microbiology.

\section{Authors' contributions \\ All authors read and approved the final manuscript.}

\section{Authors' information}

Joy Watts is the Editor-in-Chief of Environmental Microbiome and a Senior Editor of Microbiome.

\section{Publisher's Note}

Springer Nature remains neutral with regard to jurisdictional claims in published maps and institutional affiliations. 
Published online: 01 April 2019

\section{References}

1. Cania B, Vestergaard G, Krauss M, Fliessbach A, Schloter M, Schulz S. A longterm field experiment demonstrates the influence of tillage on the bacterial potential to produce soil structure-stabilizing agents such as

exopolysaccharides and lipopolysaccharides. Environmental Microbiome 2019; [production to add citation].

2. Stein JL, Marsh TL, Wu KY, Shizuya H, Delong EF. Characterization of uncultivated prokaryotes: isolation and analysis of a 40-kilobase-pair genome fragment from a planktonic marine archaeon. J Bacteriol. 1996;178:591-9.

3. Rondon MR, August PR, Bettermann AD, Brady SF, Grossman TH, Liles MR, Loiacono KA, Lynch BA, Macneil IA, Minor C, Tiong CL, Gilman M, Osburne MS, Clardy J, Handelsman J, Goodman RM. Cloning the soil metagenome: a strategy for accessing the genetic and functional diversity of uncultured microorganisms. Appl Environ Microbiol. 2000;66:2541-7.

4. Tyson GW, Chapman J, Hugenholtz P, Allen EE, Ram RJ, Richardson PM, Solovyev W, Rubin EM, Rokhsar DS, Banfield JF. Community structure and metabolism through reconstruction of microbial genomes from the environment. Nature. 2004;428(6978):37.

Ready to submit your research? Choose BMC and benefit from:

- fast, convenient online submission

- thorough peer review by experienced researchers in your field

- rapid publication on acceptance

- support for research data, including large and complex data types

- gold Open Access which fosters wider collaboration and increased citations

- maximum visibility for your research: over $100 \mathrm{M}$ website views per year

At BMC, research is always in progress.

Learn more biomedcentral.com/submissions 